\title{
EFL Learners' Literacy with and Without ER in Reading English
}

\author{
Henny Rahmawati ${ }^{1, *}$, Zobi Mazhabi $^{2}$ \\ English Education Department, Universitas Islam Malang, Jl. Mayjen Haryono Gg. 10 No.193, 65144 Indonesia \\ ${ }^{1}$ hennyrahma@unisma.ac.id*; ${ }^{2}$ zobi.mazhabi@unisma.ac.id \\ *corresponding author
}

\begin{abstract}
\begin{tabular}{l|l} 
ARTICLE INFO ABSTRACT & ART
\end{tabular}
Article history

Received 04, 20, 2020

Revised 08, 11, 2020

Accepted 08, 22, 2020

Keywords

Literacy

Extensive reading

This study aims to explore the students' beliefs towards reading between those who have followed the ER and those who have not in the distinct level of reading ability high, intermediate, and low level. This present study is a qualitative study concerning the students' perception towards a issue. The findings show that the students' beliefs, those who have followed ER with a high level of competency, towards reading English remain the same as intensive reading principles. While, unexpectedly, those who have not yet followed ER at the same level have some beliefs which refer to ER principles. Besides, the principles of intermediate and low-level students who have or have not yet followed ER remain the same, reflecting those of intensive reading. This study contributes practically to ER practitioners in implementing ER so that ER, within classroom activities, can run as it is by minimizing the biases and maximizing its benefits based on the out-comes and the students' beliefs towards reading in English. Theoretically, the contribution lies at an additional confirmation that the outputs of ER, in the form of students' beliefs, may result un-expectedly. Thus, many factors contributing to its success must be well-monitored. The conclusion and suggestions are then attached to the end of this paper.

Penelitian ini bertujuan untuk mengeksplorasi keyakinan siswa terhadap membaca antara mereka yang sudah mengkuti kelas Extensive Reading (ER) dan mereka yang belum pernah mengenal Extensive Reading pada tingkat kemampuan membaca yang berbeda tingkat tinggi, sedang, dan rendah. Penelitian ini adalah penelitian kualitatif tentang persepsi siswa terhadap kegiatan membaca teks berbahasa Inggris. Temuan menunjukkan bahwa kepercayaan siswa terhadap membaca bahasa Inggris, bagi mereka yang telah mengikuti ER pada tingkat kemampuan berbahasa level tinggi, sama dengan prinsip membaca secara intensif. Sementara, di luar dugaan, mereka yang belum mengikuti ER di tingkat yang sama memiliki beberapa keyakinan yang mengacu pada prinsip-prinsip ER. Untuk tingkat menengah dan rendah baik bagi mereka yang telah atau belum mengikuti ER, prinsip-prinsip mereka mencerminkan prinsip-prinsip membaca intensif. Studi ini memberikan kontribusi praktis untuk praktisi ER dalam menerapkan ER dalam kegiatan kelas supaya dapat berjalan sebagaimana mestinya dengan meminimalkan bias dan memaksimalkan manfaatnya berdasarkan keluaran yang didapat yakni keyakinan siswa terhadap membaca dalam bahasa Inggris. Secara teoritis, kontribusi terletak pada tambahan pengetahuan bahwa output ER, dalam bentuk kepercayaan siswa, dapat terjadi secara tak terduga karena banyak faktor yang berkontribusi pada keberhasilannya sehingga harus benar-benar dikontrol dengan baik. Kesimpulan dan saran mengenai hasil penelitian akan dilampirkan pada bagian akhir tulisan ini.
\end{abstract}

This is an open access article under the $\mathrm{CC}-\mathrm{BY}$ license.

\section{Introduction}

Reading, famously known as a receptive skill, is a pivotal aspect of language learning. A few studies on reading, therefore, have been conducted worldwide for decades, within which many aspects of reading have been exploited from intensive to extensive reading, from learners to teachers' perspectives on read- 
ing activities and so forth. Few studies, however, discussed the ways the EFL learners read in English. The different characteristics of learners-high, intermediate, and low level of course, must-read distinctively. Knowing the differing ways of reading is linear to choosing 'a gun for the soldier' in solving reading problems.

Extensive Reading (ER) is one type of reading, widely known as a joyful activity to promote reading habits within which readers read several texts (Bamford \& Day, 1998; Jacobs \& Farrell, 2012). It represents any self-selected interesting readings, at any place, at any time, in their own reading pace and without any assessment which then can possibly escalate 'a liking for reading' (Schmidt \& Richards, 2010). There are various ER benefits proven empirically, such as improving vocabulary (Daskalovska, 2018), reading habits, reading rate, comprehension, positive attitude, and motivation (Bamford \& Day, 1998). In many cases, ER has been brought to the classroom with 'mixed and matched' with some ER's features blurred, and some others can still exist, such as Guided Extensive Reading (Lestari \& Yusra, 2014), Uninterrupted Sustained Silent Reading (Krashen, 1989), and Literature Circle-oriented ER (Widodo, 2016). The absence of some features might be deemed as its flexibility since some cases report that ER aspects are difficult to control in the classroom. Nevertheless, the more existing feature of ER improves its performance.

ER features proposed by (R. Day, 1998) are famously known as the ten principles of ER. Those principles include 1) easy reading material; 2) various reading materials on a wide range of topics; 3 ) self-selected reading materials by the students; 4) a massive reading; 5) a fast reading; 6) reading for pleasure; 7) individual and silent reading; 8) reading for its own reward; 9) guided reading, and 10) reading modeled by the teachers. Regarding those features, (R. R. Day, 2015) on 38 articles coming from an international refereed journal, reveal that some features which are frequently implemented in the reviews and some other features are often ignored in the research of ER implementation.

In Indonesia context, the fame of ER seemed to be roughly similar as Japan and Korea in ten to fifteen years ago and rapidly grows as in Vietnam two years ago (Waring \& Husna, 2019). Furthermore, some previous studies discover that the reading culture of Indonesian EFL learners, at any level primary, secondary
(Delfi \& Yamat, 2017), and tertiary level (Rahmawati, 2018), is still considered low and needs to improve significantly. Therefore, some efforts have been administered to build literacy culture, particularly reading culture. In this regard, (Rahmawati, 2019) more specifically investigated the students' perception of ER featured with reading log towards their academic literacy, and the result showed a positive attitude. Even though many studies confirm the benefits of ER within classroom activities, (Iftanti, 2012) finds that the students tend to read textbook materials instead of reading for pleasure. The ways students read, as well as their beliefs in reading English, contributes practically to the teachers' effort in improving the ER implementation to maximize the benefits.

In relation to that, this study was then aimed at revealing the ways of EFL learners, who have not yet and those who have followed ER class, read. In uncovering the previous issue, this study considers the findings coming from both the low, intermediate, and high levels of reading proficiency.

\section{Method}

This study employed a qualitative method. A questionnaire provided in google forms was used to obtain data. The participants were university level students pursuing their bachelor's degree at a private university in Malang, majoring in English education. This study classifies the participants into two categories; students have immersed in the ER class and those who have not followed the ER class. Besides, for each category, the students were divided into a low, intermediate, and high level of reading proficiency based on their grades in reading classes. The obtained data were analyzed qualitatively.

This study involved ninety-two students' participants. They were asked to complete the online questionnaire and classified into students who have followed the ER and those who have not. Fifty-three students have joined the ER class, and thirty-eight students have not joined the ER class. From the former group, all respondents were qualified for the study. However, from 39 students who have not followed the ER classes, only 18 students were qualified to be the participants of this study. From each classification, they were divided into a low, intermediate, and high-level reading competency. For the former group, 24 students have high, 17 have intermediate, and 12 have low 
competencies. Meanwhile, from the second category five, nine, and four students were classified as high, medium, and low competency, respectively. The complete classification of the participant is presented in Table 1 .

Table 1. Students' Classification

\begin{tabular}{cccccc}
\hline \multicolumn{3}{c}{ Followed ER } & \multicolumn{3}{c}{ Not followed ER } \\
\hline \multicolumn{3}{c}{ 53 } & students & \multicolumn{3}{c}{ 18 } & students \\
\hline $\mathrm{H}$ & $\mathrm{I}$ & $\mathrm{L}$ & $\mathrm{H}$ & $\mathrm{I}$ & $\mathrm{L}$ \\
24 & 17 & 12 & 5 & 9 & 4 \\
$45 \%$ & $32 \%$ & $23 \%$ & $28 \%$ & $50 \%$ & $22 \%$ \\
\hline
\end{tabular}

\section{Findings and Discussion}

In classifying the students, they were asked whether they have immersed in the ER class, which was then followed by some questions asking their grades in reading classes, Reading I, II, III, and IV. For the grades, the students were also clustered into grade A (score 80), B (score 70), C (score 60), D (score 50), and $\mathrm{E}$ (score 40). The grades were later altered in digits. The average score was used to determine the students' level, high, intermediate, or low.

When the online questionnaire was distribute, not all participants have followed all the reading classes. For those who followed ER classes, fortunately, all the participants have followed all reading classes, Reading I, II, III, and IV. While the other group, from 39 students not having followed ER classes, only 18 students have followed all reading classes. Therefore, the determined participants were 53 students having followed ER and 18 students not having followed ER, with a total of 71 participants. The participant classification is presented in Table 1.

Based on Table 1, the students in each group were divided into low, intermediate, and high levels of competency-based on their grades. The classification was carried out based on the average score they got in their reading classes; $\geq 76$ as high, $75 \geq 70$ as in-terminate, and $\leq 69$ as low levels. The number of students who have followed ER classified as high, intermediate, and low levels are 24, 17, and 12, respectively. While the number of students who have not followed ER classified as high, intermediate, and low are 5, 9, and 4, respectively.
Table 1 displays that 1) most of the students who participate filling the questionnaire are those who have followed ER which can then be roughly said that ER has been widely implemented in reading classes; 2) for those who have followed ER, the highest percentage that is 45 percent comes from the high level of competency, followed by intermediate that is 32 percent and low level that is 22 percent; 3 ) for the other group, the highest percentage coming from the inter-mediate level that is 50 percent followed by the high level that is 28 percent and low level, 22 percent. Therefore, those who take the ER are more successful in general reading ability than those who do not take ER classes.

Based on the above classification, we then compiled some data regarded as the issue discussed in this study, as shown in Table 2. Table 2 demonstrates that most students believe that reading activity does not picture the principles of ER since they have followed the ER beforehand. Their beliefs possibly refer to intensive reading activities like 1) reading every word of passage, 77 percent; 2) saying the words a lot when reading, 64 percent; 3 ) reading slowly for comprehension, 34 percent; 4) knowing every word for comprehension, 44 percent; 5) looking dictionary often, 31 percent; 6) knowing the pronunciation of every word, 76 percent; and 7) learning vocabulary as the only way to improve reading ability, 64 percent out of 53 students. For a belief, that learning grammar is the only way to improve reading comprehension, more than half of the students disagree, 64 percent. Then, when asked whether they read differently towards distinct readings, most of them, 66 percent, confirmed that they read different passages the same way. Lastly, 94 percent of students agree that in reading certain English texts, they need specific methods. This belief was contrastive to the previous opinion saying that they read the different passages in the same ways. Thus, regardless of the theoretical exposures they have got from the facilitators, they are still confused in the implementation. Further, they get back to their previous reading culture intensive reading, most of EFL learners are learning to read not reading to learn; this, however, still needs further confirmation. 
Table 2. The following table figures out the questions distributed to the first group of students

\begin{tabular}{|c|c|c|c|c|c|c|c|c|c|}
\hline \multirow{2}{*}{ Statements } & \multicolumn{3}{|c|}{ Agree } & \multicolumn{3}{|c|}{ Disagree } & \multicolumn{3}{|c|}{ Undecided } \\
\hline & $\boldsymbol{H}$ & $I$ & $L$ & $\boldsymbol{H}$ & $I$ & $L$ & $\boldsymbol{H}$ & $I$ & $L$ \\
\hline It is always necessary to read every word of & \multicolumn{3}{|c|}{$41(77 \%)$} & \multicolumn{3}{|c|}{$12(23 \%)$} & \multicolumn{3}{|c|}{$0(0 \%)$} \\
\hline the passage. & 18 & 15 & 8 & 6 & 2 & 4 & 0 & 0 & 0 \\
\hline It is a good idea to say the words aloud & \multicolumn{3}{|c|}{$34(64 \%)$} & \multicolumn{3}{|c|}{$18(34 \%)$} & \multicolumn{3}{|c|}{$1(2 \%)$} \\
\hline when you read. & 12 & 14 & 9 & 12 & 2 & 3 & 0 & 1 & 0 \\
\hline Reading more slowly improves & \multicolumn{3}{|c|}{$34(64 \%)$} & \multicolumn{3}{|c|}{$19(36 \%)$} & \multicolumn{3}{|c|}{$0(0 \%)$} \\
\hline comprehension. & 16 & 7 & 11 & 8 & 10 & 1 & 0 & 0 & 0 \\
\hline Knowing every word is necessary for & \multicolumn{3}{|c|}{$44(83 \%)$} & \multicolumn{3}{|c|}{$9(17 \%)$} & \multicolumn{3}{|c|}{$0(0 \%)$} \\
\hline comprehension. & 19 & 16 & 10 & 5 & 1 & 2 & 0 & 0 & 0 \\
\hline As you read, you should always look up the & \multicolumn{3}{|c|}{$31(59 \%)$} & \multicolumn{3}{|c|}{$22(42 \%)$} & \multicolumn{3}{|c|}{$0(0 \%)$} \\
\hline $\begin{array}{l}\text { meaning of words you do not know in the } \\
\text { dictionary. }\end{array}$ & 11 & 11 & 9 & 13 & 6 & 3 & 0 & 0 & 0 \\
\hline To read well, you need to know the & \multicolumn{3}{|c|}{$40(76 \%)$} & \multicolumn{3}{|c|}{$13(25 \%)$} & \multicolumn{3}{|c|}{$0(0 \%)$} \\
\hline pronunciation of every word. & 18 & 12 & 10 & 6 & 5 & 2 & 0 & 0 & 0 \\
\hline Learning vocabulary is the only way to & \multicolumn{3}{|c|}{$34(64 \%)$} & \multicolumn{3}{|c|}{$17(32 \%)$} & \multicolumn{3}{|c|}{$2(4 \%)$} \\
\hline improve reading ability. & 15 & 11 & 9 & 8 & 6 & 2 & 1 & 0 & 1 \\
\hline Learning grammar is the only way to & \multicolumn{3}{|c|}{$19(36 \%)$} & \multicolumn{3}{|c|}{$34(64 \%)$} & \multicolumn{3}{|c|}{$0(0 \%)$} \\
\hline improve reading ability. & 6 & 5 & 8 & 18 & 12 & 4 & 0 & 0 & 0 \\
\hline You can read all kinds of texts (books, & \multicolumn{3}{|c|}{$35(66 \%)$} & \multicolumn{3}{|c|}{$18(34 \%)$} & \multicolumn{3}{|c|}{$0(0 \%)$} \\
\hline newspapers, etc.) the same way. & 14 & 10 & 12 & 10 & 7 & 0 & 0 & 0 & 0 \\
\hline Reading in English requires some reading & \multicolumn{3}{|c|}{$50(94 \%)$} & \multicolumn{3}{|c|}{$3(6 \%)$} & & $0(0 \%)$ & \\
\hline methods. & 23 & 16 & 12 & 0 & 1 & 1 & 0 & 0 & 0 \\
\hline
\end{tabular}

According to Table 2, those who agree that reading every word is necessary for reading; the highest percentage is from the high-level students. Additionally, this is also the highest percentage of all senior students, 75 percent. At the same time, the highest percentage of intermediate and low-level students that agree to that statement is 63 and 67 percent, respectively. Hence, they share the same belief in read- ing. For the second statement, fifty percent of the high-level students agree that reading aloud is a good idea when reading, and the other fifty disagreed with that statement. For the remaining two levels, this statement also gains the highest percentage. The more detailed information about students respond to the questionnaire are presented in Table 3.

Table 3. The ways to read mostly done by students (the first group)

\begin{tabular}{ll}
\hline Level & Reading Beliefs \\
\hline High & Reading every word of passage (75\%) \\
& Reading aloud (50\%) \\
& Reading slowly (67\%) \\
& Knowing every word to read (79\%) \\
& Not looking up dictionary often (54\%) \\
& Knowing the pronunciation of every word (75\%) \\
& Learning vocabulary to improve reading ability (63\%) \\
& Learning grammar is not the only way to improve reading (75\%) \\
& Using the same way to read different kinds of text (58\%) \\
& Requiring some reading methods to read in English (96\%) \\
& Reading every word of passage (88\%) \\
& Reading aloud (82\%\%) \\
& Slow reading does not improve reading comprehension (56\%) \\
& Knowing every word to read (94\%) \\
& Looking up dictionary often (65\%) \\
& Knowing the pronunciation of every word (50\%) \\
& Learning vocabulary to improve reading ability (65\%) \\
& Learning grammar is not the only way to improve reading (71\%) \\
& Using the same way to read different kinds of text (59\%) \\
& Requiring some reading methods to read in English (94\%) \\
& Reading every word of passage (67\%) \\
& Reading aloud (75\%) \\
\hline &
\end{tabular}




\begin{tabular}{ll}
\hline Level & Reading Beliefs \\
\hline Slow reading does not improve comprehension $(56 \%)$ \\
Knowing every word $(92 \%)$ \\
Looking up dictionary often (75\%) \\
Knowing the pronunciation of every word to read (83\%) \\
Learning vocabulary to improve reading ability (75\%) \\
Learning grammar is not the only way to improve reading (67\%) \\
Using the same way to read different kinds of text (100\%) \\
Requiring some reading methods to read in English (100\%) \\
\hline
\end{tabular}

The above findings, furthermore, show that even if they have followed some ER classes, more than fifty percent of the participants still believe that doing intensive reading help them more. Regardless of whether they know exactly how to do ER in their reading activities, they remain using comforting activities for them. Those activities, then, become their beliefs in reading comprehension. Some of them, below fifty percent, however, have some opinions referring to as ER principles. This possibly because they have followed their teacher's explanation during class time, and then they have practiced the ways accordingly though in some cases, it was not comfortable for them at first. However, after they gain benefits from those activity, they start to believe in them. This study, however, does not discuss the reasons why they agreed, disagreed, or even undecided; this study focuses more on their beliefs towards reading activities. Table 4 presents how students who have not followed the ER before thinking about their reading activities.

Table 4. The following table figures out the questions distributed to the participants who have not yet followed ER

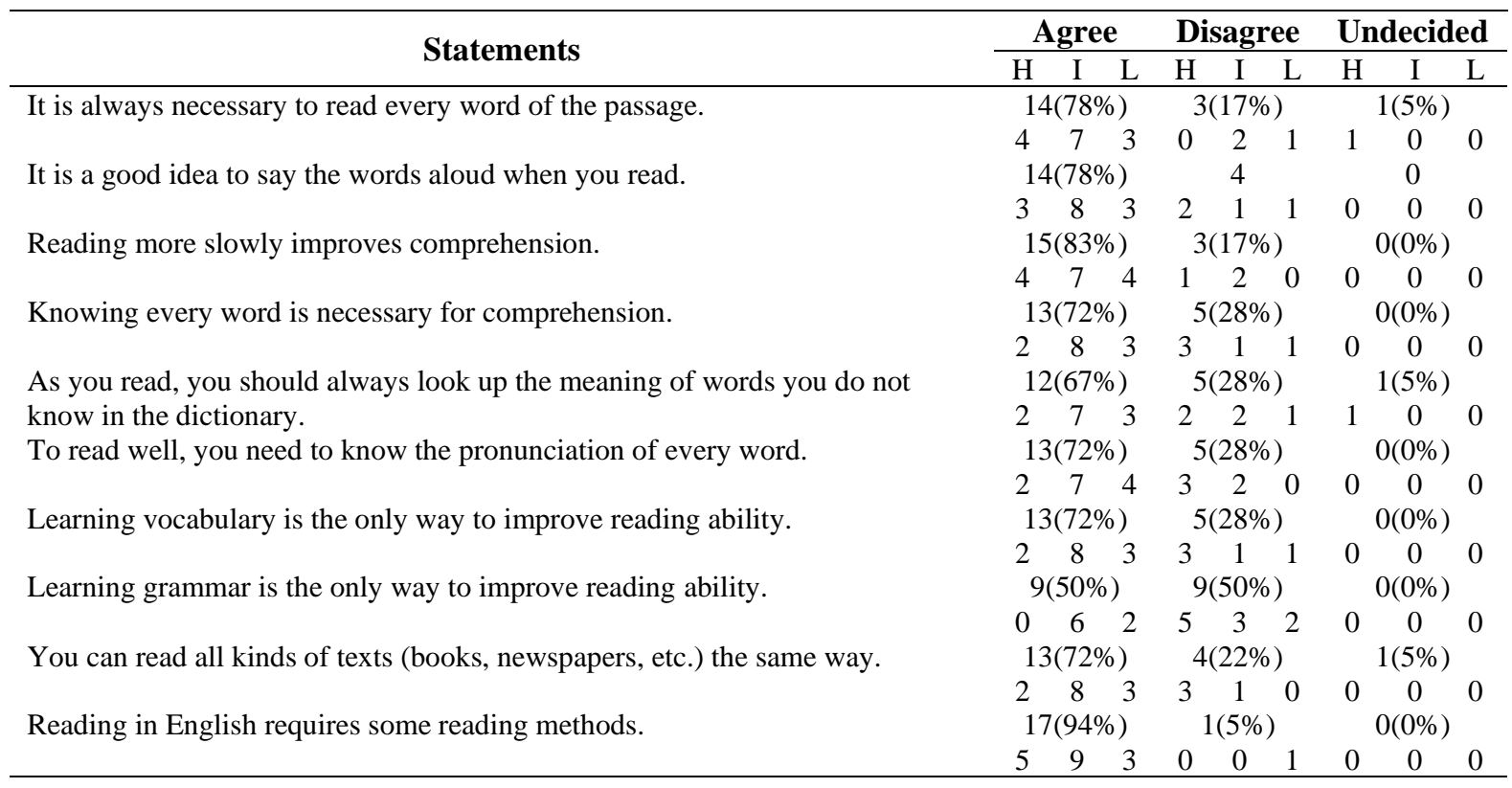

Based on Table 4, the students who have not followed ER before, more than fifty percent, believe that reading every word 78 percent, reading aloud 78 percent, reading more slowly 83 percent, knowing every word 72 percent, looking up dictionary often 67 percent, knowing the pronunciation of every word 72 percent, and learning vocabulary 72 percent are key points to reading comprehension. While learning grammar, fifty percent of students believe that it is essential for reading comprehension. The percentage is more significant than in the previous group; this possibly because they are not yet exposed to ER activities. The finding is, however, still needs to be confirmed in further study, since the number of participants between those two groups is not equal. Further-more, thirteenth students, 72 percent, read all kinds of texts in the same way. In this case, 94 percent of the students agree that reading in English requires some reading methods. That represents their awareness that 
they need to be exposed to some reading methods to texts. In Table 5, we classified the way the students high, intermediate, and low level read English readings.

Table 5. The ways to read mostly done by students (the second group)

\begin{tabular}{|c|c|}
\hline Level & Reading Beliefs \\
\hline \multirow[t]{10}{*}{ High } & Reading every word of passage ( $80 \%)$ \\
\hline & Reading aloud $(60 \%)$ \\
\hline & Reading slowly (80\%) \\
\hline & $\begin{array}{l}\text { Knowing every word is not necessary } \\
\text { for reading comprehension }(60 \%)\end{array}$ \\
\hline & Not looking up dictionary often $(60 \%)$ \\
\hline & $\begin{array}{l}\text { Knowing the pronunciation of every } \\
\text { word to read }(60 \%)\end{array}$ \\
\hline & $\begin{array}{l}\text { Learning vocabulary is not the only } \\
\text { way to improve reading ability }(60 \%)\end{array}$ \\
\hline & $\begin{array}{l}\text { Learning grammar is not the only way } \\
\text { to improve reading }(100 \%)\end{array}$ \\
\hline & $\begin{array}{l}\text { Not using the same way to read differ- } \\
\text { ent kinds of text }(60 \%)\end{array}$ \\
\hline & $\begin{array}{l}\text { Requiring some reading methods to } \\
\text { read in English }(100 \%)\end{array}$ \\
\hline \multirow[t]{10}{*}{ Intermediate } & Reading every word of passage $(78 \%)$ \\
\hline & Reading aloud $(89 \%)$ \\
\hline & $\begin{array}{l}\text { Slow reading does not improve com- } \\
\text { prehension }(78 \%)\end{array}$ \\
\hline & Knowing every word to read (89\%) \\
\hline & Looking up a dictionary $(78 \%)$ \\
\hline & $\begin{array}{l}\text { Knowing the pronunciation of every } \\
\text { word to read }(78 \%)\end{array}$ \\
\hline & $\begin{array}{l}\text { Learning vocabulary to improve read- } \\
\text { ing ability }(89 \%)\end{array}$ \\
\hline & $\begin{array}{l}\text { Learning grammar is not the only way } \\
\text { to improve reading }(67 \%)\end{array}$ \\
\hline & $\begin{array}{l}\text { Using the same way to read different } \\
\text { kinds of text }(89 \%)\end{array}$ \\
\hline & $\begin{array}{l}\text { Requiring some reading methods to } \\
\text { read in English }(100 \%)\end{array}$ \\
\hline \multirow[t]{11}{*}{ Low } & Reading every word of passage $(75 \%)$ \\
\hline & Reading aloud $(75 \%)$ \\
\hline & $\begin{array}{l}\text { Slow reading does not improve com- } \\
\text { prehension }(100 \%)\end{array}$ \\
\hline & Knowing every word to read (75\%) \\
\hline & Looking up dictionary often $(75 \%)$ \\
\hline & $\begin{array}{l}\text { Knowing the pronunciation of every } \\
\text { word }(100 \%)\end{array}$ \\
\hline & $\begin{array}{l}\text { Learning vocabulary to improve read- } \\
\text { ing ability }(75 \%)\end{array}$ \\
\hline & $\begin{array}{l}\text { Learning grammar is not the only way } \\
\text { to improve reading ( } 50 \%)\end{array}$ \\
\hline & Using the same way to read different \\
\hline & kinds of text $(75 \%)$ \\
\hline & $\begin{array}{l}\text { Requiring some reading methods to } \\
\text { read in English }(75 \%)\end{array}$ \\
\hline
\end{tabular}

Table 5 reveals that the high-level students in the second group, six out of ten, beliefs they have referred to the ER principles though they have not followed the ER class before. This finding was objected to the fact that they are not yet exposed to the ER. The reasons why they have such beliefs must be first confirmed in further study. For intermediate and low level, the opinions are almost the same.

Based on the above explication, for the high level of reading competency, the students exposed to ER tend to have beliefs referring to the intensive reading activities. This partly confirmed by (Kayi-Aydar, 2013) that more teachers still treat ER as a peripheral activity, with a focus on intensive reading strategies than conducting ER as it must be. Besides, this positively confirms a study conducted by (Waring \& Husna, 2019) that regardless of the massive ER implementation in Asia context, including Indonesia, unfortunately, some students and teachers have even not reached the Introduction Stage not knowing ER very well and how to practice it within the classroom as well as not having sufficient materials to read. This, technically, can hinder the emerging benefits of ER in language learning. For the intermediate and low levels, the beliefs remain the same that is lesser than intensive reading principles

The finding for the second group remains unexpected. Before they are exposed to the ER, they have already had some principles referring to ER activities. From this point, it can be roughly concluded that ER principles are innately found within those who have not exposed to ER activities either inside or outside the classroom, primarily students with a high level of proficiency in reading. For those in the high level of reading ability, they have read English texts as fun activities. Most of them do not consult the dictionary they read and do not regard grammar and pronunciation as the most critical aspect in reading though they still slowly read every word. Some reasons, however, must be considered for this finding, which needs further investigation. While for intermediate and low levels, their beliefs toward reading fit the expected results, they are more likely to practice intensive reading activities.

\section{Conclusion}

The students, who have had ER class, beliefs towards reading, remain the same as intensive reading principles. For the intermediate and low level, their beliefs tend to be close to 
intensive reading principles. In contrast, unexpectedly, those who have not followed the ER and have a high level of reading capability have some beliefs which refer to ER principles. For the intermediate and low-level students who have or have not yet followed the ER, their principles are the same, reflecting intensive reading principles. Therefore, in implementing ER, the teachers must ensure that the students, specifically those who have a high level of reading capability, have already loved to read even before they are exposed to ER. When implementing ER, teachers must sharpen these beliefs and not the other way around. This study, however, needs to be confirmed in a different context with many more participants.

\section{References}

Bamford, J., \& Day, R. R. (1998). Teaching Reading. Annual Review of Applied Linguistics, 18(March), 124-141. https://doi.org/10.1017/s0267190500003512

Daskalovska, N. (2018). Extensive reading and vocabulary acquisition. In The idea and practice of reading (pp. 25-40). Springer. https://doi.org/10.1007/978-981-10-857273

Day, R. (1998). Top Ten Principles for Teaching Extensive Reading. Reading in a Foreign Language, 14(2), 136.

Day, R. R. (2015). Extending extensive reading. Reading in a Foreign Language, 27(2), 294-301.

Delfi, S., \& Yamat, H. (2017). An analysis of reading performances of Indonesian EFL learners for extensive reading practice. Journal of Educational Sciences, 1(1), 3544. https://doi.org/http://dx.doi.org/10.31258/jes.1.1.p.35-44

Iftanti, E. (2012). A survey of the english reading habits of EFL students in Indonesia. Teflin Journal, 23(2), 149-164. https://doi.org/10.15639/teflinjournal.v23i2/149-164
Jacobs, G., \& Farrell, T. S. (2012). Teachers sourcebook for extensive reading. Information Age Publishing Inc.

Kayi-Aydar, H. (2013). Exploring classroom discourse: Language in action. ELT Journal, 67(2), 268-270. https://doi.org/$10.1093 /$ elt/cct004

Krashen, S. D. (1989). Language acquisition and language education: Extensions and applications. Prentice Hall International New York.

Lestari, Y. B., \& Yusra, K. (2014). Investing academic speaking through guided extensive reading: A case study in extensive reading class at English Department Mataram University Indonesia. In Proceedings of the 61st Teflin International Conference, 412-415.

Rahmawati, H. (2018). English literacy culture of university level EFL learners: How literate are they? JEES (Journal of English Educators Society), 5(1), 79-89. https://doi.org/10.32682/jeell.v5i1.947

Rahmawati, H. (2019). The students' perception on academic reading log for essay writing literacy: Some influential points. JEES (Journal of English Educators Society), 4(1), 66. https://doi.org/10.21070/jees.v4i1.1948

Schmidt, R., \& Richards, J. C. (2010). Longman dictionary of language teaching \& applied linguistics. In Reading in a foreign language. Pearson Education, Inc.

Waring, R., \& Husna, N. (2019). Expectations and experiences of indonesian teachers who have, and have not, done extensive reading. Teflin Journal, 30(2), 153-170. https://doi.org/10.15639/teflinjournal.v30i $2 / 153-170$

Widodo, H. P. (2016). Engaging students in literature circles: Vocational english reading programs. Asia-Pacific Education Researcher, 25(2), 347-359. https://doi.org/10.1007/s40299-015-0269-7 